\title{
Practical theology: Can it really help the local congregation?
}

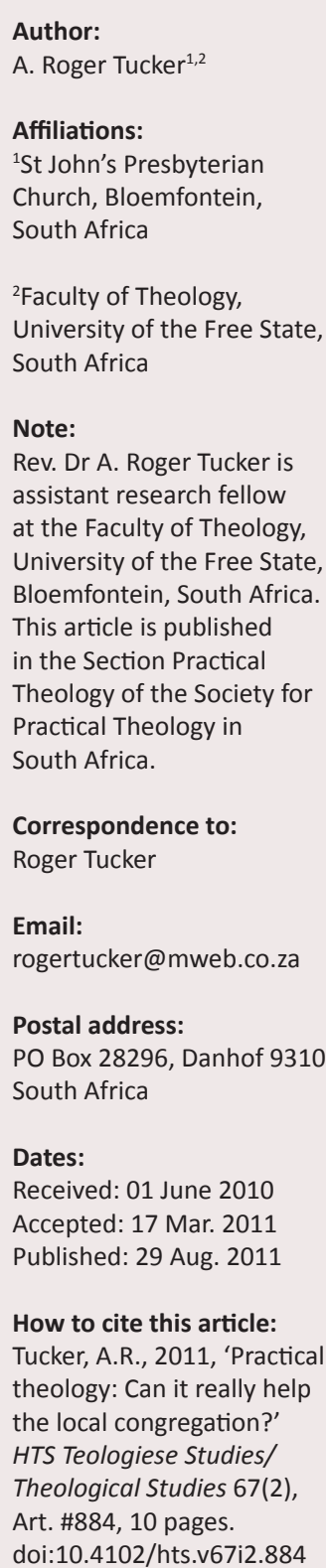

(C) 2011. The Authors. Licensee: AOSIS OpenJournals. This work is licensed under the Creative Commons Attribution License.
This article sought to demonstrate that a synthesis of various church growth methods used within the framework of Heitink's (1999:124ff.) three theory of action perspectives, namely the 'hermeneutical', 'empirical' and 'strategic', has successfully enabled the building up of one congregation both structurally and spiritually. The 'building up' concept was drawn from the practical theological subdiscipline of 'building up the local church'. This subdiscipline judges the success of God's work in a local congregation by how effective it is in mobilising its members, facilitating growth towards holistic maturity, making disciples and serving others in mission. Since 2006, St John's has moved towards this goal by mobilising its members into four new ministry teams (with 13 subsidiary teams), which appear to have achieved growth in these areas.

\section{Introduction}

This article sets out to provide one example of where a congregation has been lead through a change process, using the analytical discipline of practical theology, so that it appears to have become more effective in fulfilling God's purpose for it in terms of the subdiscipline of building up the local church. It seeks to provide a positive answer to the question in Nel's (2009a) article, first asked by Ammermann (2005:1): 'Should congregations be analysed at all because they are so different as communities of faith?'

After briefly outlining the assumptions on which the change process was based, it then describes the strategic planning procedures employed to try and build up St John's since 2006 and the theological sources and authors from which they originated. This description is schematised using Heitink's (1999:124ff.) three action perspectives.

If the literature cited in the account of the planning process seems a little out of date today, it must be remembered that it was the only literature available to the author (a full-time minister) and congregation prior to 2005. The sources that are cited are books and articles that were used in the agogical-teleological process and demonstrate a selection of some of those that will be available to other ministers and church leaders to equip them in building up their congregations, although it must be remembered that new literature is appearing all the time.

Many of the books mentioned in the description of the developmental process were not made available to or read by the St John's leadership. The author either made extracts of them or else used them as a resource in teaching and discussion.

\section{Assumptions}

\section{God builds his church, but we must work (using the wisdom he has given us)}

In an exegesis of Psalm 127, Möller (1987:222ff.) comments that 'in vain' is the dominant refrain of this psalm. To build effectively, the church needs to begin by rediscovering the 'in vains' of Psalm 127. There are three things that we cannot do without God's help: To build a house, keep watch over a city or provide for our needs. Jesus' words in John 15:5 (New International Version [NIV]) may be a commentary on this psalm: 'For apart from me you can do nothing'. In this case, in our modern self-sufficient technocratic society, we have to admit that much of what we try to do may be 'in vain'; we cannot produce results, only he can.

Yet, although building begins with God, is empowered by God and we often make mistakes, we have to work trusting in the grace of God. He needs builders, people who will work, teachers, evangelists, pastors, apostles and every church member. The walls of Jerusalem were only rebuilt when the people committed themselves to the labour under Nehemiah. 'So we built the wall. And all the wall was joined together to half its height, for the people had a mind to work' (Neh 4:6, English 
Standard Version [ESV]). The watchmen need to watch for trouble. The prophets need to warn the congregation. Everyone needs to pray: 'And we prayed to our God and set a guard as a protection against them day and night' (Neh 4:9 ESV). There needs to be organisation and administration, such as supplied by Nehemiah.

Moreover, the Bible encourages us to use our God-given wisdom and the resultant scientific approach in searching for God's vision for us and our local congregation. Calvin recognised that:

Our wisdom, in so far as it ought to be deemed true and solid wisdom, consists almost entirely of two parts: the knowledge of God and of ourselves ... these are connected by many ties, and it is not easy to determine which of the two precedes and gives birth to the other.

(Calvin, n.d. Institutes 1:1)

So, although the conclusions that we draw from the more 'scientific' approaches will always be provisional and are always subject to the proviso that a sovereign God can and does intervene at times to confound its conclusions, there is an important place for the combined theological and scientific approach of practical theology.

\section{Effective building up requires embracing God's desire for newness}

The God who has revealed himself in the Scriptures is a creative God, who is always doing something new; for instance, in Isaiah 43:19 (ESV) we read: 'Behold, I am doing a new thing ...' Moltmann (1996:27ff.) calls this the category 'novum'. The 'novum' was what the prophets proclaimed. They proclaimed the God of history as the creator of a new future. Likewise, the category 'novum' dominates the eschatological language of the New Testament. God wants to express that newness and creativity through the local congregation. He delights in a congregation that allows this to happen.

\section{Effective building up requires the application of all three of Heitink's Theological Theory of Action Perspectives}

The practical theological theory proposed by Heitink (1999) is employed, as opposed to that developed recently by Osmer (2008), because of the systematic way Heitink uses the three action perspectives the author considers vital for strategic planning. Heitink (1999:148) developed a 'theological theory of action as the core of a practical-theological theory'. Its foundational idea comes from the assumption that social science theories of communicative action provide an adequate basis for a scientific and systematic understanding of how praxis and theory relate. This is compatible with the central importance that the Judaeo-Christian scriptures attach to communication as deed and action. The testimony of these scriptures is that Yahweh creates and rules by 'powerful, sovereign, generative speech' (Brueggemann 1997:146). When he speaks, the thing is done. As Jacob (1955) comments:

The word of God in the Old Testament directs and inspires a single history which begins with the word of God pronounced at creation and which is completed by the word made flesh (John $1: 14)$.

(Jacob 1955:129)

This compatibility with the scriptures is vital, because practical theology is, 'a theological operational science and an empirical theological approach' (Heyns \& Pieterse 1990); therefore, its prime theological task is reflecting theologically and scientifically on the complex interweaving of the elements of Christian ecclesiological praxis (Zerfass 1974:164). Thus, it must not only do justice to scripture, but also with the social context within the parameters of a theological and biblical hermeneutic. This raises the challenge of integrating the theological and empirical approaches by means of a theory that is acceptable both theologically and also to the operational sciences. Habermas and Ricoeur offer theories that Heitink (1999) integrates to fulfil this role.

Habermas (1981) creates a theory of communicative action, in order to develop a hermeneutic that critically interprets the current empirical-analytical practice of the operational sciences. He seeks to link the intuitive, relational, cultural 'lifeworld' with the rational 'system' of bureaucratised society, the marketplace and science. Knowledge is perpetuated and mediated in society both by the 'lifeworld' and the 'system'. The 'lifeworld' may be equated with the hermeneutical aspect and the 'system' with the empirical aspect of knowledge. The latter provides the means whereby the lifeworld may be criticised and thus, is the basis for a sociocritical hermeneutic (Thiselton 1992:387). The theory provides an epistemological rational for the integration of the theological and empirical perspectives in practical theology (Heitink 1999:102, 135ff.).

Ricoeur (1991:144-145) proposes a theory of action that stresses the similarities between the interpretation of social reality and the interpretation of texts. 'A text is detached from the spoken word and an inscription of a social phenomenon is detached from the original concrete acts' (Ploeger 1999:75). This suggests that there is a dialectical relationship between the understanding of an action (the text) and its explanation (the context). Both understanding and explanation are necessary if the meaning of an action is to be discerned.

Thus, as a further step, Heitink (1999:163ff.) is able to equate understanding with the hermeneutical method of theology and explanation with the empirical method of the operational sciences. The hermeneutical perspective is integrated with the empirical perspective (understanding with explaining) using the hermeneutical circle of understanding, first developed explicitly by Schleiermacher (Thiselton 1992:204; Heitink 1999:180, 196). Thus, an integrative theory that is philosophically acceptable to the operational sciences is produced (Heitink 1999:102, 166).

The hermeneutical perspective is one that combines the insights of theology and the social sciences to interpret reality (Heitink 1999:192ff.). The empirical perspective seeks to arrive at an explanation of reality of a social system by 
analytically and scientifically examining it, connecting 'who does what?' with 'where and when' (Heitink 1999:220) and testing any explanations quantitatively. The strategic perspective seeks not only to predict future events, but also to steer them to a desired end through management and planning (Heitink 1999:201); however, as 'unpredictable unforeseeable, emergent processes, breaks in life processes and in routines' (Welker 1994:99) will inevitably arise, the smooth flow and progression of any institution towards its self-conceived goals will always be challenged by the unexpected (Van der Ven 1996:436-439).

Heitink (1999:102) contends that in 'responding to any practical-theological question one faces a hermeneutical, an empirical, and a strategic perspective', therefore, it would seem to be a logical deduction that mediating the Christian faith in the praxis of any local congregation to effectively build it up requires the consideration and application of all three perspectives.

\section{Effective building up requires a uniquely defined purpose for each congregation within the limits imposed by their interpretation of the scriptures}

Nel (2009b:443ff.) makes the point that because the ecclesiology, history and social context of every local congregation is different and often no longer determined by denomination, building up requires that each local congregation discovers its own unique identity. This must then be translated into its own unique hermeneutically and empirically defined purpose if it is to lead to effective building up. The author agrees with Nel (2009a:241) that the only truly authoritative text for any Christian congregation must be the Bible and that any purpose, however unique and contextual, must be compatible with a biblical hermeneutic.

\section{Effective building up requires a synthesis of many methods and approaches}

It follows from Nel's (2009b) observations that because of the differences between each local congregation, no one method will work and be effective for all either in part or in total. It is the experience of the author, from 36 years in the ministry of the Uniting Presbyterian Church of Southern Africa (UPCSA), that many ministers and church leaders are looking for the 'magic bullet'. By this I mean, one method that will completely work for every local congregation, despite the congregation's identity and context. Sometimes it may seem to work and be the complete answer, but on the whole, it leads to failure. Even where it seems to work it usually means that the congregation has missed out on the advantages that come from discerning their unique identity.

As Osmer (2010:5) comments, 'church leaders cannot even assume that a program working well in one congregation will work in a similar congregation in another part of their own country'; therefore the author believes that a local congregation will only be effectively built up by creatively and analytically using a synthesis of the various methods and approaches, such as described, for instance, by Nel (2010a), in a mix and match manner that is appropriate to the particular context of that congregation.

\section{Hermeneutical perspective Foundational principles for strategic planning}

The planning process at St John's was built upon the principle that building up the local congregation is a work of the Trinitarian God, upon whom we need to rely and listen to (Barth 1956:643; Moltmann 1977:50ff.). He is concerned for the effectiveness of local congregations and has a unique plan for each one. He is willing to reveal the steps necessary for the congregation to take in order to achieve this plan so that his missional purpose may be achieved through that congregation. This missional purpose can only be effectively fulfilled by the empowering of the Holy Spirit, by rediscovering its call to discipleship and remaining faithful to its doctrinal basis (Watson 1983; Nel 1990).

\section{Traditional church and kingdom model influences within the congregation}

It was discerned that three church and kingdom models have traditionally influenced St John's. Firstly, the church or kingdom as institution model (Dulles 1987:34-46; Snyder 1991:56-76), secondly, the 'church as herald' model (Dulles 1987:76ff.) and thirdly, as an important minority influence, the church or kingdom as 'mystical communion' model (Dulles 1987:47ff.; Snyder 1991:56ff.). The institution model's effects on the congregation are that being Presbyterian, as well as the sacred space of the sanctuary are important, the minister is the focal point of church life, that 'things have to be done in the right way' and that the church exists mainly for the sake of its members; thus, survival is its primary purpose. The church as herald model's effects has added an important Bible-centred, evangelistic, missional element and preaching focus to the life of the congregation. The primary purpose of the church is seen as making disciples of all nations. Thirdly, as an important minority influence, the 'mystical communion' model's effects have emphasised informal and interpersonal community. The goal of the church becomes spiritual growth and a deepening of community.

This meant that there would be significant minority support for change, especially amongst the leadership, because of the missional and relational influences of the herald and mystical communion models. On the other hand, because of the strong institutional model influence, it also meant that if it was to be accepted by the congregation as a whole it would need to be managed well; thus, it would need to be participatory, include as many members as possible, be servant centred, build up trust by starting with readily accepted changes and require God to 'miraculously' give the leadership the hearts of the congregation. This striving for unity is vital, given that secondary and primary level groups in the congregation often have differing, uncoordinated agendas and goals which may lead to 'departmentalization and fragmentation' and prevent change (Malphurs 1993:160; Gibbs \& Coffey 2001:224).

\section{Discerning paradigms}

Much of the developed world, including South African society, is characterised by three main competing 
epistemological perspectives: the traditional, modern (or enlightenment) and the postmodern (Hendriks 1999:85ff.). These three paradigms have all influenced significant sections of the membership of St John's. They give rise to differing perceptions of reality, of how knowledge is attained, attitudes to authority, of how socialisation occurs and ideas about religious experience. This produces different generational tastes (Gibbs \& Coffey 2001:12) and seemed to show that the church needed to cater to a range of these tastes in teaching, preaching, communication (such as using Facebook and Twitter), worship, relating and so forth.

\section{St John's values discerned}

The next step was to discern the congregation's values. In 2006, after much thought and discussion Session, decided upon the existing denominational (UPCSA) values, as well as the special values unique to our congregation, which we wished to emphasise. These are included in full, because everything else that happened was built upon them:

\section{The divine inspiration, inerrancy and authority of Scripture}

The original words found in the Bible have been revealed to its authors by God, through the agency of the Holy Spirit in such a way that they wrote exactly what he wished to be written, without error or mistake, so that they accurately impart divine truth. As such, they are determinative and authoritative for every believer in all areas of doctrine, life, morals and conduct; therefore, everything we do, teach and preach at St John's is based on the Bible.

\section{The necessity of the new birth}

In order for the individual to have the spiritual blessings promised by the Bible, it is necessary for each individual to experience regeneration for themselves, which Jesus called 'being born again' (Jn 3:3). These blessings primarily include justification, the forgiveness of sins, eternal life, glorification, the indwelling presence of Christ and the Holy Spirit, becoming a child of God, redemption and sanctification. Those who have truly experienced the new birth have security in the completed atoning work of Christ and will persevere as true Christians, until they are glorified when Jesus returns; therefore, our aim is that every member experiences this new birth and knows that they have assurance of salvation and eternal life because of this.

\section{Specific concrete missional objectives (need-oriented evangelism)}

God desires every congregation to be involved in mission. Mission means that the congregation is focusing its activity on those outside the congregation, with the object of contacting, relating to and serving non-Christians so that they come to a saving faith in Christ. These activities must be specific, which means that they must be focused on a particular human hurt, hope or need. They must also be concrete, in that they actually deliver effective help; therefore, we ask every member to support our mission activities within the congregation, in Bloemfontein, in the Free State, in South Africa and in the world.

\section{Caring and loving relationships}

The concept of community is central to the body of Christ. God desires that every congregation builds itself up through loving and caring relationships. Each member endeavours to love and care for the other, as God has gifted him or her. The greater and more intimate the depth of love, the healthier that body will be; accordingly, we want to be a community of friends. We encourage every member to be friendly and to let others make friends with them.

\section{Corporate, dynamic, inspiring worship}

Inspiring worship comes when, first of all, there is a strong sense of it being corporate. This means that there is participation, belonging, togetherness, unity and community shared by the worshippers throughout the whole service. Secondly, it means that there is a dynamic engendered because of a sense of movement into God's presence. This stirs the worshippers and leads to profound help and hope being experienced. For that reason, when we worship we ask our members to come expecting to meet Jesus, to participate and to be changed by the preaching of the word and the power of the Holy Spirit.

\section{Significant relational groups}

The most effective way to make friends and to grow as a Christian is to become involved in a small group. God's plan is that, when it is possible, a Christian belongs to a small group (less than 15 people), who love and care for them. These small groups may be centred on Bible study, a discipleship program, praying, fellowship or an activity or ministry; therefore, we encourage our members to become involved in a small group.

\section{A gift orientated lay ministry}

God has equipped congregations with gifted people (see $\mathrm{Rm}$ 12:6-8; 1 Cor 12; Eph 4) to accomplish his purpose. The role of the church leadership is to help members identify their gifts and to integrate them into appropriate ministries. This process must be led by the Spirit, involve trial and error and be done with much prayer. When Christians function in their area of gifting, they generally function less in their own strength and more in the power of the Holy Spirit and as a result, are far more effective. Consequently, we expect every member to be involved, as God has gifted them in helping the congregation attain its God-given missional objectives.

\section{Passionate spirituality}

Congregations that are effective for God are on fire for him and his work. The members live committed lives and practice their faith with joy and enthusiasm. They view prayer, both individual and corporate, as an inspiring experience that alone enables them to accomplish the impossible, change the world and achieve God's purposes. They have a similar attitude towards using the Bible and other factors affecting personal spirituality. Accordingly, we encourage every member to grow in their relationship with the risen Christ through the developing their prayer life and increasing in applied knowledge of the scriptures. 


\section{Intentional discipleship development}

Congregations which experience passionate spirituality, spiritual growth, a gift oriented ministry and strong leadership resources have a continual, quality teaching, equipping and developmental ministry both at a small group and congregational level. Individuals are being continuously taught the riches of God's word, stretched in their personal development and educated in the needs of the world, so that their God given gifts and potential are being developed and released. Therefore, we expect members to consciously seek to grow as disciples of Jesus.

\section{God-given vision}

A biblical vision for a congregation may be defined as seeing the future that God has promised for that church and the purpose for which he brought it into existence. The final responsibility for discerning vision rests with the elders. Vision may come through hearing God's direct word, reading the Bible, dreams, prophecies, impressions God puts on hearts and minds, joint counsel in an atmosphere of prayer or seeing needs that God tells us to meet. God-given vision always has the purpose of multiplying his spiritual offspring. God wants every Christian to be part of a church that has a God-given vision. Therefore we would encourage the body of Christ at St John's to join with the leadership in seeking this unique vision.

This was circulated to all the second tier leadership and is now shared with all wishing to enter into membership.

\section{Empirical perspective}

The drift towards stasis in any organisation often means that the church only begins to change when it feels the affects of adverse empirical factors, as suggested by Zerfass (1974:167). As far as St John's was concerned, there were several factors motivating the felt need to change.

\section{Decline in worship attendance}

It was the perception that morning worship attendance had declined markedly since 2000 (although no numerical attendance records were kept). This was reinforced by the fact that the number of services had been reduced from three on a Sunday in 2000, to one by 2005. A number of factors contributing to this decline are set out below.

\section{Aging demographic profile}

Perhaps the most obvious reason for this decline in worship attendance was the aging demographic profile of the congregation. The fact that half the congregation was over 50 years of age was a danger signal according to Gibbs and Coffey (2001:20), signifying that something needed to be done. These factors led to the leadership deciding that the congregation was indeed in need of major structural redevelopment, when Rendle and Mann's (2003:225) congregational life cycle was considered. This suggests that there are three stages in the life of every congregation: growth, peaking and decline. Growth needs guidance, to stay at peak vitality and effectiveness needs continual revival and when in decline, a congregation needs to redevelop its structures.

\section{Demographic change in Bloemfontein}

The English-speaking White population of Bloemfontein is diminishing. As a result the number of those who might attend an English-speaking church was decreasing. The congregation faces the challenge that many young people move to bigger centres or emigrate overseas. Members, especially professionals who can acquire jobs, are emigrating overseas, as well as many of all economic ranking 'emigrating' to the South African coast on retirement. This trend has continued and since 2006 there has been a very high mortality rate (43 deaths in four years) amongst church members, as well as emigration to the coast or overseas (approximately 30).

\section{Perception of the irrelevance of the church amongst certain sectors of South African society}

Another factor that is probably affecting membership and attendance is the observation made by Hendriks (1995:27; 1999:89), 'that those who are "leaving" the church seem to be white and "coloured" affluent people' because they either see no need of it or perceive the church to be a minor role player in shaping the destiny of the world. St John's is affected by this trend, given that it has historically been $99 \%$ White and had many in professional occupations in its membership.

\section{Inappropriate style of ministry for the size of the congregation}

A final internal contributing factor to this decline in attendance is that St John's has traditionally been a 'pastor centred' congregation. According to Hendriks (2004:40ff.), the size of a pastor-centred congregation may range from 70 to 200 active members, although it may have a membership roll of anything up to 1000. This type of congregation expects its needs to be met through a personal relationship with the pastor. Many pastors in these congregation experience great frustration and even burnout, trying to meet all the expectations. Gifted pastors have struggled for many years with this at St John's. It was therefore decided to transition St John's, to become a 'program centred' congregation, whereby lay-leaders would lead teams and groups that would initiate ministry.

\section{Contextual factors that cannot be controlled}

As they verbalised and considered the reasons for this decline, the leadership were able to realise that some of the causes for the decline in membership and worship attendance were as a result of contextual and demographic factors that were outside of their control. Roozen and Hadaway's (1993:34, 1995:56) research has revealed that this contextual and demographic influence is, in fact, also the case with many congregations in the United States. Thus, there was no point looking for people in the congregation or leadership to blame either now or in the past. 


\section{Hope factors}

Yet there were several positive considerations. The congregation was still large with a membership of 350. This is large according to Callahan's (1983:xxiv) research. Many were progressing to spiritual maturity and provided a good pool of committed Christians. There was core of younger people, aged below 40, still involved. The congregation is situated in a central position in Bloemfontein (being within average trip time of most of the residents of the city [Callahan 1983:xviii]). It is in an attractive location that people want to come to. It has been traditionally a receptor church (see George 1991:31ff.) and still could be.

These factors encouraged the leadership to take the step of faith, believing that God still had a purpose for St John's and much could still be accomplished if they assumed responsibility for this. The leadership enthusiastically did so and thus, took the first step of fulfilling its function as an interpretive guide, which Osmer (2008:18ff.) considers to be one of its main roles.

\section{The strategic perspective}

In March 2006, the author was called to the pastoral charge of St John's Presbyterian Church in Bloemfontein. In the remainder of 2006, the Session spent much time discerning what the basic values of the congregation were (as indicated previously). Callahan (1983, 1987, 1990), Nel (1990, 1994), Schwartz (1996) and Watson (1983) were particularly helpful in this process. Ten basic doctrinal and ecclesiological values were discerned, which became the springboard from which a mission statement was formulated and the future direction of the church decided upon.

\section{Strategic Planning Committee Retreat}

This future direction was finalised at a Strategic Planning Committee Retreat (SPCR) (see Callahan 1987:1ff.), attended by 30 congregational leaders. The retreat integrated teaching, prayer and listening to God and sharing each other's stories as part of the planning process. The participants were then presented with eight activities based upon the previously discerned values and asked to choose five for implementation over the next three years. This involved either deciding to extend and build upon what were existing strengths or add new activities that had previously been neglected. An example of the questionnaire provided for the leadership to complete for just one of these values, namely that concerning specific concrete missional objectives (need-oriented evangelism) is shown in appendix 1. Filling in the form resulted in a score, which gave a more objective idea of how the congregation was doing in that particular area. It also enabled comparison between the eight value based activities, which was hoped would aid in the decision making process.

Then the mission statement was discussed, which through final group consensus focused on mobilising the congregation in order to serve Jesus by making disciples and serving the world in mission. It reads: 'The purpose of St John's is that we all be equipped and built up by each other in order to reach out in mission thus fulfilling the Great Commission'. The five value-based activities chosen had to be implemented with the purpose of achieving this missional goal.

The five value-based activities chosen for development were: Corporate dynamic worship (see Callahan 1983:24ff.); caring and loving relationships (see Schwarz 1996:36ff.); intentional discipleship development (see Watson 1981; Nel 1990; Dunn 1992:87ff.; Getz 1994:110ff.); specific concrete missional objectives (see Callahan 1983:1ff.) and strong leadership resources (see Callahan 1983:41ff.; Schwarz 1996:22ff.).

The conclusions of the 2007 retreat were presented to the Session at St John's (the ruling body) for ratification and/ or modification and the Session was asked to select a Strategic Planning Steering Committee (SPSC) (see Callahan 1987:57ff.) to implement the decisions of the retreat. Since the first meeting in 2007, there have been three more Strategic Planning Committee Retreats (in 2008, 2009, 2010) in order to monitor and fine-tune the planning process.

\section{Strategic Planning Steering Committee}

The SPSC consisted of 10 people with a balance of strengths, as suggested by Callahan (1987:61ff.). It met 25 times. The SPSC's job fell into the following categories:

- The establishment of a three-year time-line for the staggered implementation of each of the tasks pertaining to a particular value (see Callahan 1987:25ff; see Figure 1).

- The formulation of the initial steps that needed to be undertaken if each activity was to be implemented and making the appropriate recommendations to the Session.

- The appointment of ministry teams (see Malphurs 2005:57ff.) to become responsible for the action of each of these tasks and the future development. The monitoring of the process once it had been handed over to each ministry team.

\section{Formation of ministry teams}

By the middle of 2009, four new major ministry teams had been established in the congregation, each consisting of from four to ten members. These were a worship team, a pastoral caring team, a mission and outreach team and what eventually became a discipleship and leadership team. In so far as possible, a church member could only be on one team. These teams then motivated and recruited people over a three year period, for 13 subsidiary teams, that were assigned for the purpose of oversight to one of these major teams (see Figure 2, an organogram for mid 2010). By the end of 2010, there were a few minor changes and additions.

\section{Summary of principles underlying choices informing the strategic process}

As a result of the conservative nature of the congregation and its age profile, it was decided to transition using Lewin's 


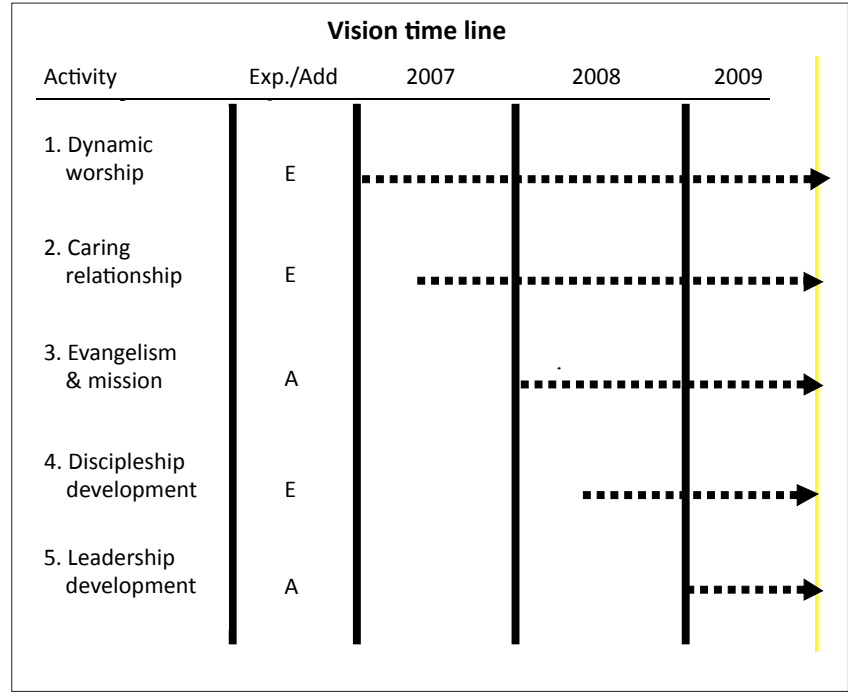

E, an activity that was an existing strength but which could be expanded upon; A, a new activity that needed to be added.

Dotted arrow indicates approximate date started to implement activity.

FIGURE 1: Vision timeline.

(1969) 'unfreezing-moving-freezing' model for the process. This also required the adoption of a participatory ongoing planning process that involved all the leadership, in which the congregation was informed of every decision. This style may be regarded as a high relational and high task style (see Nel 1994:41-43).

It also soon became obvious that this strategic process required a continuing re-evaluation and discernment of God's will as problems occurred and circumstances changed. In a postmodern society, changes now come rapidly and with little warning, making it sometimes difficult to engage in long term strategic planning (Gibbs \& Coffey 2001:36). In fact, many congregations in urban societies in the developed world are experiencing an almost complete membership turn-around every five to ten years (Woods 1996:139ff.).

As indicated previously, the 'ministry team' concept described by Malphurs (2005:57ff.) was adopted, rather than the committee approach. This approach promotes relationships and service in line with St John's values, because the concept promotes ministry over governance, relational interaction over attending meetings and the selection of ministry team members on the basis of calling and gifting rather than duty.

\section{Results}

As a consequence of this planning and by God's grace, there was significant quantitative mobilisation of the congregation, as well as what seems to be a qualitative increase in the holistic maturity of many in the body and its corporate effectiveness in making disciples and serving others in mission.

\section{Corporate dynamic worship}

The morning worship family service has been transformed to allow for the participation of all ages, led by a team of laity and pastor (Callahan 1983:xiii). From anecdotal accounts, this does indeed provide significant hope and help for many (aided by a healing subsidiary team that prays for people after the service) and a sense of belonging (Callahan 1983:24) all of which has contributed to the transformation of some lives. A 'Welcomer's team' has been enthusiastically supported by continuous fresh recruits and has led to the incorporation of some visitors into the congregation. An evening worship service has also been started. As a result, five worship groups meeting the felt needs of a wide age range now serve the church.

\section{Caring and loving relationships}

Caring and loving relationships have been enhanced by the establishment of a pastoral caring team which visits and cares for the infirm, hospitalised and housebound. In addition, a subsidiary 'hospitality' team has organised many social functions (after the worship service tea and coffee, films, dances, braais, a talent spotting concert and so forth) and a prayer chain has started, both of which have contributed to this objective.

\section{Intentional discipleship development}

The development of this objective only began at the end of 2009. Those activities that were arranged to help achieve this activity was an ongoing Crown Financial Ministries course, as a result of the global recession (attended so far by 30 members), a weekend Lay Witness Mission (each main event attended by approximately 150 people, including visitors) and a week's Bible School with visiting speakers lecturing on Jeremiah and Leadership (attended by 60 members). This has resulted in the establishment of three more midweek small groups. Evidence for the results in people's lives is again necessarily anecdotal, but has been very positive, with testimonies to conversion, a new desire to relate to Jesus, be involved in the life and work of St John's and serve the kingdom of God in mission.

\section{Specific concrete missional objectives}

One of the first teams established (in 2007) was responsible for implementing this objective. Since then, the missional activity of the congregation has grown to include involvement of members with an AIDS orphanage, the establishment and running of a Soup Kitchen at Rocklands (a township near Bloemfontein), helping the UPCSA congregation at Rocklands to purchase and put up a large meeting tent, showing the 'Jesus Film' in Zambia, Pondoland and in the informal settlements around Bloemfontein (on a weekly basis) and raising financial and prayer support for four missionary families serving outside South Africa.

\section{Leadership resources}

As a result of the involvement of many with these other teams, there were almost no members available for the leadership development team and it was combined with the discipleship team; however, teaching on leadership was given 


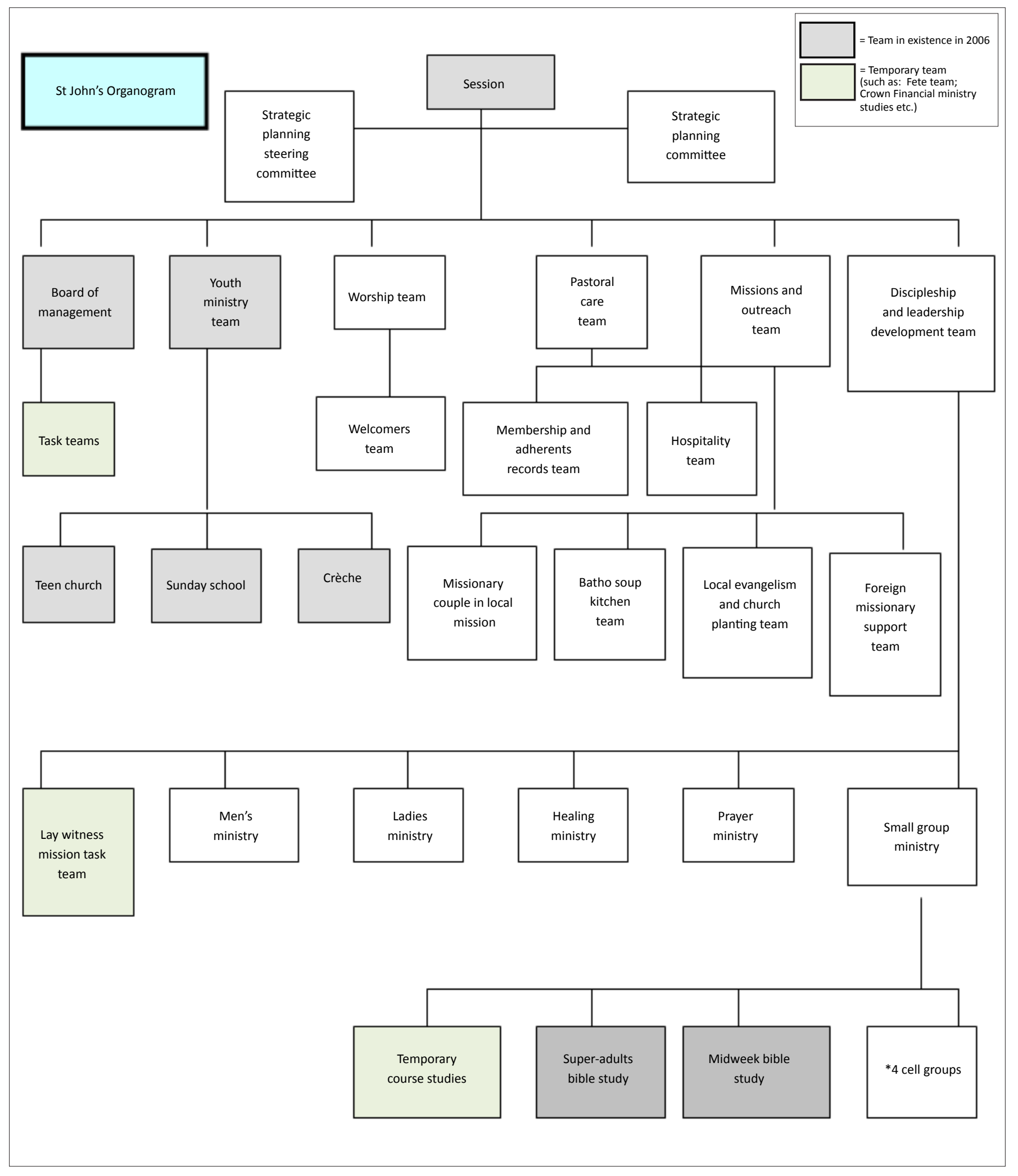

FIGURE 2: St John's Organogram.

at the week's Bible School in October 2010. St John's has tried to develop leaders through the involvement of leaders and potential leaders with the regular yearly retreat. It has also tried to improve its leadership structures and processes by several innovations. The congregation have been regularly informed at worship services of the changes and their opinions invited. Complaints are immediately responded to and evaluative criticism encouraged, including from those outside the official leadership structures. Participation in the teams has mobilised many. The Session meeting is also participatory, where every opinion is welcomed and every plan for the future discussed and prayed about to discern God's will. The leadership structures have been streamlined by the development of a church structure organogram. 


\section{Summary}

There have been disasters, mistakes, a little conflict and a few who have either started attending worship services at other churches in Bloemfontein because of dissatisfaction with what was happening or just dropped out of church altogether. Yet, on the whole, the unity of the congregation has been maintained and as many, perhaps more than 100 members have been mobilised through the team and small group structures with the aim of helping the congregation fulfil its mission and achieve the objectives set at the first retreat in 2006. Whilst the overall membership roll of the congregation is still contracting in size as a result of contextual factors outside of its control, 26 people have become members since 2007, of whom most have begun to take an active role in the life of the congregation.

The process has taken longer than was foreseen at the original retreat in January 2007 and is still requiring continuous development. In 2010, the original SPSC was disbanded and the planning process put under the auspices of the Session. However, as another cycle of planning begins it will be necessary to set up another SPSC team, bearing in mind that not all our basic values have yet been implemented and we will continuously face new challenges.

Despite the superficial appearance the organogram gives that everything is in place and working, that is not the case. Some teams are not functioning effectively and some leaders are unable to initiate and motivate; however, the point is that the team structure is there and provides a framework in which to work, reveal problems and deal with them, develop and improve.

Now that there has been the redevelopment of congregational structures (albeit an ongoing process) the leadership believes that we are now ready to begin to start seeking revival from God. The ditches have been dug and the congregation must wait upon God to fill them with the water of the Spirit, according to an allegorical 'prophetic' interpretation of 2 Kings 3:16-17 which was aptly applied to St John's at a leadership meeting.

\section{Conclusion}

The St John's experience in conjunction with Nel's (2009a, $2009 b)$ two recent papers would seem to indicate that practical theology has a vital role to play in building up the local congregation in a holistic manner. It provides the theoretical foundation that enables many methods and research findings to be integrated used in an analytical and strategic manner.

Therefore, it is recommended that every step be taken to make these resources available to ministers and church leaders. To do this, certain problems must be overcome: Many ministers associate practical theology with an 'unevangelical theology' and perceive it as being 'in vain', because it depends upon man's scientific efforts at the expense of dependence upon God and it is often couched in very academic language.
I hope that this article will help to begin to dispel the idea that conservative evangelicals cannot employ practical theology. It also should indicate that practical theological methods need to be applied with much prayer and listening to God and his Word.

However, one major challenge remains. There are the 'how to' books about church growth or building up the local church, which often neglect the serious theological or theoretical basis or only deal with it in a shallow manner and the academic books that are difficult for the educated layman or even average minister to understand. It seems that only rarely will the twain meet in satisfactory manner. It would appear that Schwarz (1999) has tried to remedy this lack in his book, Paradigm Shift in the Church, by presenting a theological and social science apologia for his methods. Whilst this is informative and seems to be based on Kuhn's (1970) work, the author still finds it lacking in presenting a satisfactory biblical hermeneutic for his approach.

Moreover, despite the admirable efforts of some academics, which have proved very helpful, the author believes that there needs to be a much greater effort to communicate the method and findings of practical theology in much less academic language, which will enable it to be understood and applied by the average UPCSA minister or church leader, for example. Somehow, it needs to bridge the gap between academia and the local minister, to become as influential as it deserves to be.

In addition, although many good and very useful ideas occur in the literature as to what must be done in a local congregation; the long term structural implementation is not dealt with very effectively. Only Callahan's (1983) approach seems to deal with the nitty-gritty of the actual planning process and structure needed. Schwarz and Schalk (1998) have published an implementation guide to the 'natural church development' Schwarz (1996) proposes, but it is weak on the structural implementation. Furthermore, it is suggested that, despite Callahan's $(1987,1990)$ detailed and very useful implementation guides, a major weakness is that these guides give ministers and leaders little guidance as to how to effectively structurally implement the three to five year plan, once the SPSC has been established and decided upon its objectives, other than employing the timeline principle (which is very useful). Neither does it deal with what is supposed to happen once the three to five years strategic plan is finished. In the author's opinion, Malphur's (2005:56ff.) team approach is the only one that begins to fill the structural gap and even then, this is not spelt out in detail.

The experience at St John's demonstrates that practical theology can help build up a local congregation. But if practical theology is to increasingly help local congregations, it is the author's contention that these challenges mentioned need to be addressed in the coming years. 


\section{TABLE 1: Rating guide}

\section{Item}

Your Assessment

Number of Points

Our church has one major mission activity that is delivering effective help and is contacting, relating to and serving nonChristians so that they come to faith in Christ.

Our church has one major mission activity that is delivering effective help and is contacting, relating to and serving nonChristians so that they come to faith in Christ.

Our church has one major mission activity that is delivering effective help and is contacting, relating to and serving nonChristians so that they come to faith in Christ.

I know one person that has come to openly profess Christ either at a Sunday service or as a result of a St John's missional programme over the last year.

I know one current member of St John's that has led one other person to openly profess Christ through personal contact in the last year.

I know one person who has come to openly profess conversion as a result of my cell group activities during the last year.

\section{APPENDIX 1}

\section{Questionnaire used at the first strategic planning retreat in 2006 One section of questionnaire used at the first strategic planning retreat in 2006}

Specific concrete missional objectives (need-oriented evangelism) (based in part on Callahan's [1983:10] questionnaire, modified and added to, to be appropriate to St John's).

\section{Definition}

God desires every congregation to be missional. Missional means that the congregation is focusing its activity on those outside the congregation, with the object of contacting, relating to and serving non-Christians so that they come to a saving faith in Christ. These activities must be specific, which means they must be focused on a particular human hurt, hope or need. They must also be concrete in that they actually deliver effective help.

\section{Questions:}

1. List up to three present major missional objectives that you know that St John's is accomplishing in your community.

2. Write down one person that you know has come to openly profess Christ either at a Sunday service or as a result of a St John's missional programme over the last year.

3. Write down one current member of St John's that you know has led one other person to openly profess Christ through personal contact in the last year (you may include yourself!).

4. Write down name of one person who has come to openly profess conversion as a result of your cell group activities during the last year.

\section{References}

Ammermann, N.T., 2005, Pillars of faith: American congregations and their partners, University of California Press, Berkeley.

Barth, K., 1956, Church Dogmatics, IV.1:The Doctrine of Reconciliation, ed. G. Bromiley \& T. Torrence, transl. G. Bromiley, T \& T Clark, Edinburgh.

Brueggemann, W., 1997, Theology of the Old Testament, Fortress Press, Minneapolis.

Callahan, K. \& Tanner, I., 1983, Twelve Keys to an Effective Church, Harper, San Francisco.

Callahan, K.L., 1987, Twelve Keys to an Effective Church - The Leader's Guide, Harper \& Row, San Francisco.

Callahan, K.L., 1990, Twelve Keys to an Effective Church - The Planning Workbook, HarperCollins Publishers, San Francisco.

Calvin, J., nd., Institutes, MacDonald Publishing Company, Florida.

Dulles, A., 1987, Models of the Church, Doubleday, New York.

Dunn, J., 1992, Jesus' Call to Discipleship, Cambridge University Press, Cambridge.

George, C., 1991, Prepare Your Church for the Future, Fleming H. Revell, Grand Rapids. Getz, G., 1994, Sharpening the Focus of the Church, Victor Books, Wheaton.

Gibbs, E. \& Coffey, I., 2001, Church Next, Inter-Varsity Press, Leicester.

Habermas, J., 1981, Theorie des kommunikativen Handelns, Suhrkamp, Frankfurt am Main.

Hendriks, J., 1999, Religion in South Africa: Census'96, Article in South African Christian Handbook. Edited by Froise, M, Christian Info, Welkom.

Hendriks, H.J., 2004, Studying Congregations in Africa, Lux Verbi. BM., Wellington.

Heyns, L. \& Pieterse H., 1990, A Primer in Practical Theology, Gnosis, Pretoria.

Jacob, E.,1958, Theology of the Old Testament, transl. A. Heathcote \& Allcock P., Hodder \& Stoughton, London.

Kuhn T., 1970, The Structure of Scientific Revolutions, University of Chicago Press, Chicago.

Lewin, K., 1969, Grundzüge der topologischen Psychologie, H. Huber, Bern.

Malphurs, A., 1993, Pouring New Wine into Old Wineskins, Baker Books, Grand Rapids. Malphurs, A., 2005, Leading leaders, Baker Books, Grand Rapids.

Möller, C., 1987, Lehre vom Gemeindeaufbau, Band 1, Vandenhoeck \& Ruprecht, Göttingen.

Moltmann, J., 1977, The Church in the Power of the Spirit, transl. M. Kohl, SCM Press, London.

Moltmann, J., 1996, The Coming God, Fortress Press, Minneapolis.

Nel, M., 1990, Building Up the Church, NG Kerkboekhandel, Pretoria.

Nel, M., 1994, Who are we?, Malan Nel (self-published), Pretoria.

Nel, M., 2009a, 'Revisited: Empirical Approaches', HTS Teologiese Studies/Theological Studies 65(1), 230-242.

Nel, M., 2009b, Congregational Analysis: A theological and ministerial approach, HTS Teologiese Studies/Theological Studies 65(1), 432-448.

Osmer, R., 2008, Practical Theology, An introduction, William B. Eerdmans Publishing Co., Grand Rapids.

Osmer, R., 2010, Practical Theology: Current International Perspective, Lecture notes distributed at Practical Theology in South Africa Congress, University of Pretoria, Pretoria in January 2010

Ploeger, A., 1999, 'Practical Theology and the Praxis of the Church', International Journal of Practical Theology, Walter de Gruyter, 3, 68-93.

Rendle, G. \& Mann, A., 2003, Holy Conversations, The Alban Institute, New York.

Ricoeur, P., 1975, 'Biblical Hermeneutics', Semeia 4, 33.

Ricoeur, P., 1991, From Text to Action, Northwestern University Press, Evanston.

Roozen, D. \& Hadaway, C., 1993, Church and denominational growth: What does and what does not cause growth or decline, Abingdon Press, Nashville.

Schwarz, C., 1996, Natural Church Development, Church Smart Resources, Barcelona.

Schwarz, C. \& Schalk, C., 1998, Implementation Guide to Natural Church Development, ChurchWise, Randhart.

Schwarz, C., 1999, Paradigm Shift in the Church, Church Smart Resources, Barcelona. Snyder, H., 1991, Models of the Kingdom, Abingdon, Nashville.

Thiselton, A., 1992, New Horizons in Hermeneutics, Zondervan Publishing House, Grand Rapids.

Van der Ven, J.A., 1996, Ecclesiology in Context, William B. Eerdmans, Grand Rapids. Watson, D., 1983, Discipleship, Hodder and Stoughton, London.

Welker, M., 1994, God the Spirit, Fortress Press, Minneapolis.

Woods, J., 1996, Congregational Megatrends, The Alban Institute, New York

Zerfass R., 1974, 'Praktische Theologie als Handlungswissenschaft', in Klostermann, F. (ed.), Praktische Theologie Heute, p. 3-33, Kaiser Grünewald, München. 